\title{
SUPPRESSIVE EFFECTS of CERTAIN VITAMINS and ORGANIC ACIDS AGAINST Meloidogyne incognita on OKRA PLANT AND THEIR ROLE in IMPROVING HOST GROWTH UNDER GREENHOUSE CONDITIONS.
}

Refaei, A. R.

Nematology Res. Unit., Agricultural Zoology Dept., Fac. Agric., Mansoura Univ., Egypt.

\begin{abstract}
A pot experiment was conducted to determine the effects of six vitamins i.e. ascorbic acid, citric acid, folic acid, nicotinic acid, pyridoxine and thiamine in comparison with oxamyl against Meloidogyne incognita infecting okra plant under greenhouse conditions. Obviously, all tested materials ameliorated plant growth and reduced number of root galls and eggmasses of $M$. incognita to distinguished degrees. Among the tested compounds, ascorbic acid treatment ranked first in ameliorating okra plant length $(75.9 \%)$, total plant fresh weight $(75.0 \%)$ and shoot dry weight $(111.1 \%)$, followed by nicotinic acid and thiamine, whereas citric acid and pyridoxine showed the least values of the same plant growth parameters comparing to nematode alone. Moreover, ascorbic acid application accomplished the greatest reduction percentage values of 82.7 and $96.6 \%$ for number of root galls and eggmasses, followed by folic acid in reducing root galls (81.2\%) and eggmasses number $(96.6 \%)$, respectively. Whereas, nicotinic acid and thiamine showed considerable records for the same nematode parameters with values of 75.7 and $90.5 \%$ each. However, oxamyl as a nematicide ranked first in suppressing root galling $(96.9 \%)$ and eggmasses number $(99.1 \%)$, but ranked the third in improving okra plant fresh weight.
\end{abstract}

Keywords: Organic acid, vitamins, ascorbic acid, citric acid, folic acid, nicotinic acid, pyridoxine, thiamine, Meloidogyne incognita, Oxamyl.

\section{INTRODUCTION}

Okra, Abelmoschus esculentus $\mathrm{L}$. is considered to be one of the most important commercial vegetable crops in most countries including Egypt. Plant parasitic nematodes, i.e Meloidogyne spp. caused significant damage and losses to most agricultural crops, including okra in the tropical and subtropical agriculture (Luc et al., 2005). Of the root-knot nematodes, Meloidogyne incognita (Kofoid \& White) Chitwood is considered to be the most popular species which affects major field and vegetable crops and caused great economic damages.

Role of selective vitamins, organic acids and antioxidants chemicals to improve plant conditions and / or inducing resistance to susceptible plants is a required target for nematode management. The eminent role of vitamins, organic acids and antioxidants in improving animal body performance and animating resistance to pathogens has encouraged scientists to utilize such chemicals to gain similar effect on plants. The application of some vitamins, organic acids or antioxidants as foliar spray or aqueous solution on root-knot nematode infected economic plants have proved that they could suppress 
Refaei, A. R.

gall formation as well as eggmasses number on such root system and improved plant growth (Zacheo et al., 1977; Al-Sayed \& Thomason, 1988; AlSayed, 1990; Kesba, 1999\&2003; Molinari, 2001; Nandi et al., 2003 and Saeed, 2005). In 1993, Osman reported the effect of aqueous solutions of Larginine, L- glutamic acids and ascorbic acid on M. javanica egg hatch and fecundity of nematode females in susceptible tomato roots. He found that all tested compounds significantly suppressed egg hatchability and resulted in $100 \%$ mortality of nematode juveniles after 7 days exposure at $2000 \mathrm{ppm}$. He also reported that application of aqueous solution of all tested compounds at $1000 \mathrm{ppm}$ significantly reduced numbers of nematode population, mature females and eggmasses in tomato roots. Abdel-Momen et al., (2005) studied the effect of ascorbic acid, salicylic, citric acid, lysine and thiamine on juveniles mortality and reproduction of $M$. javanica and the growth of sunflower in-vitro and greenhouse and reported that ascorbic acid at 2000 $\mathrm{ppm}$ gave zero reproduction factor (Rf) but not at $1000 \mathrm{ppm}$ in greenhouse test. Moreover, Ibrahim (2007) studied the response of $M$. javanica infected soybean plants to seed soaking in aqueous solution of ascorbic acid, indole acetic acid and thiamine at 500 and 1000 ppm for five hours before sowing in a pot exprement and found that the tested chemicals obviously suppressed galling and reproduction of $M$. javanica.

The objective of the present investigation was to study the suppressive effects of certain vitamins i.e. ascorbic acid, folic acid, nicotinic acid, pyridoxine and thiamine as well as organic acid i.e. citric acid in comparison with oxamyl against $M$. incognita infecting okra plant under greenhouse conditions.

\section{MATERIALS AND METHODS}

\section{- Nematode inoculm:}

Fresh hatching second-stage juveniles $\left(\mathrm{J}_{2}\right)$ of $M$. incognita were obtained from a pure culture established from a single eggmass of $M$. incognita that previously identified according to the characteristics of its perineal pattern (Taylor and Sasser, 1978), maintained and propagated on coleus plants, Coleus blumei on a bench in the greenhouse of Nematology Research Unit, Faculty of Agriculture, Mansoura University, Egypt, where this work was done. Sufficient inoculum of $M$. incognita $\left(\mathrm{J}_{2}\right)$ from soil was extracted by sieving and modified Baerman-techique (Goodey, 1957).

- Nematicide:

Oxamyl (Vydate 24\% L), Methyl - N'N'- dimethyl-N \{(methyl) carbamyloxy\}-1-thioxamidate) was used at the recommended dose of $0.3 \mathrm{ml} / \mathrm{pot}$.

- Impact of vitamins and organic acid on Meloidogyne incognita infecting okra plant under greenhouse conditions.

A greenhouse experiment was carried out to study the impact of ascorbic acid, citric acid, folic acid, nicotinic acid, pyridoxine and thiamine in comparison with oxamyl against $M$. incognita infecting okra plant. Twenty seven plastic pots $10-\mathrm{cm}-\mathrm{d}$ filled with steam-sterilized sandy loam soil 
$(1: 1)(v: v)$ were plants with three seeds of okra cv. Hybrid Dokki-2 /pot, irrigated with water as needed and then thinned at one seedling / pot after three weeks. Twenty four seedlings were then separately inoculated with 800 second stage juveniles of $M$. incognita $\left(\mathrm{J}_{2}\right)$ and $5 \mathrm{ml}$ of the dilution of such compound under study was added after one day from nematode inoculation. Each of the tested chemicals was used at the concentration of $1000 \mathrm{ppm}$ by adding $0.1 \mathrm{~g}$. from each compound into $100 \mathrm{ml}$ distilled water in a jar to become at the final concentration of $1000 \mathrm{ppm}$, then $5 \mathrm{ml}$ of this dilution was used and added to each treated pot as previously mentioned, whereas, oxamyl was used at the recommended dose $(0.3 \mathrm{ml} / \mathrm{pot})$ at the same time of adding the chemical compounds. Three seedlings were left free of nematode $(\mathrm{N})$ and untreated that served as healthy plants (check). Each treatment was replicated three times. Treatments were as follows:
1. Ascorbic acid,
2. Citric acid,
3. Folic acid,
4. Nicotinic acid,
5. Pyridoxine acid,
6. Thiamine,
7. Oxamyl,
9. Plant free of $\mathrm{N}$ and untreated.
8. $\mathrm{N}$ alone and

Pots were arranged in a randomized complete block design in a greenhouse bench maintained at $25 \pm 5^{\circ} \mathrm{C}$. Plants received water and were protected by conventional pesticides against mites and insects as needed. Plants were harvested after 45 days from nematode inoculation. Data dealing with plant length and fresh weights of shoot and root, and shoot dry weight were determined and recorded. Number of galls and eggmasses of $M$. incognita per each root system of okra plant was also counted and recorded. Root gall index (RGI) and eggmasses index (El) were estimated according to the scale given by Talyor and Sasser,(1978) as follows $: \therefore 0=$ no galling or eggmasses, $1=1-2$ galls or eggmasses; $2=3-10$ galls or eggmasses; $3=11-30$ galls or eggmasses; $4=31-100$ galls or eggmasses and $5=$ more than 100 galls or eggmasses per root system of okra plant.

Data were statistically subjected to analysis of variance (ANOVA) (Gomez and Gomez, 1984) and means were compared by Duncan's multiple range test (Duncan, 1955).

\section{RESULTS AND DISCUSSION}

Data as tabulated in table (1) represent the effect of all tested materials, (vitamins i.e. ascorbic, thiamine, pyridoxine, folic acid and nicotinic acid; and citric acid as organic acid) in comparison with oxamyl against $M$. incognita infecting okra plant. Results reveal that these materials were selective in enhancing or inhibiting plant growth parameters i.e. shoot and root fresh weights and lengths; and shoot dry weights. Remarkable enhancement in root criteria in most treatments was observed. Yet, it was not the case in shoot parameters and even adverse effect was found in some cases where such values were lesser than those plants free of nematode and untreated check. Obviously values of increment in plant growth criteria were variable and more or less significant in certain case, especially between 
Refaei, A. R.

nematode alone and all tested treatments. Oxamyl (as a nematicide) ranked third in value of percentage of increase of whole plant fresh weight by $49.6 \%$, while it was the fourth in value of plant length $102.2 \%$ comparing to nematode alone. Among tested materials, ascorbic acid (vitamin C) ranked first in percentage increase of plant length, total fresh weight of plant and shoot dry weight by $75.9,75.0$ and $111.1 \%$, respectively, followed by nicotinic acid(vitamin $\left.\mathrm{B}_{3}\right) \quad(68.1,58.1$ and $88.8 \%)$ and thiamine (vitamin B1) $(54.9$, 32.4 and $71.1 \%$ ), whereas the least values of those plant parameters recorded by citric acid and pyridoxine (vitamin $\mathrm{B}_{6}$ ) which were amounted to $20.8,21.4$ and $20.0 \%$; and $20.6,28.2$ and $15.5 \%$, respectively, comparing to nematode alone. Moreover, the intermediate increments in plant growth characters i.e. plant length, plant fresh weight and shoot dry weight was achieved by folic acid (vitamin B9) with values of $32.8,28.4$ and $26.7 \%$, respectively, comparing to nematode alone. It was noticed that plant free of nematode and untreated showed a significant difference concerning plant parameters over most tested treatments, especially that of nematode alone. Meanwhile, it recorded values of $29.4,33.5$ and $62.2 \%$ as percentage of increase in plant length, whole plant fresh weight and shoot dry weight, respectively. (Table 1 ).

Table 1: Impact of certain vitamins and organic acids on growth parameters of okra plants infected with Meloidogyne incognita under greenhouse conditions.

\begin{tabular}{|c|c|c|c|c|c|c|c|c|c|c|}
\hline \multirow{3}{*}{ Treatments } & \multicolumn{10}{|c|}{ * Plant growth response } \\
\hline & \multicolumn{2}{|c|}{$\begin{array}{c}\text { Plant length } \\
(\mathrm{cm})\end{array}$} & \multirow{2}{*}{\begin{tabular}{|c|}
$\begin{array}{c}\text { Total } \\
\text { Length } \\
(\mathrm{cm})\end{array}$ \\
\end{tabular}} & \multirow{2}{*}{$\begin{array}{c}\text { Inc. } \\
\%\end{array}$} & \multicolumn{2}{|c|}{$\begin{array}{l}\text { Fresh } \\
\text { wt.(g.) }\end{array}$} & \multirow{2}{*}{$\begin{array}{c}\text { Total } \\
\text { F.wt } \\
\text { (g.) }\end{array}$} & \multirow{2}{*}{$\begin{array}{c}\text { Inc. } \\
\%\end{array}$} & \multirow{2}{*}{\begin{tabular}{|c|} 
Shoot \\
Dry wt. \\
(g.)
\end{tabular}} & \multirow{2}{*}{$\begin{array}{c}\text { Inc. } \\
\%\end{array}$} \\
\hline & Shoot & Root & & & Shoot & Root & & & & \\
\hline Ascorbic acid & $\begin{array}{c}49.83 \\
a b\end{array}$ & $\begin{array}{c}44.00 \\
a\end{array}$ & 93.83 & 75.9 & $\begin{array}{c}6.11 \\
a\end{array}$ & $\begin{array}{c}2.15 \\
a b\end{array}$ & 8.26 & 75.0 & $\begin{array}{c}0.95 \\
a\end{array}$ & 111.1 \\
\hline Citric acid & $\begin{array}{l}38.30 \\
\text { cd }\end{array}$ & $\begin{array}{c}26.17 \\
a b\end{array}$ & 64.47 & 20.8 & $\begin{array}{c}3.61 \\
b\end{array}$ & $\begin{array}{c}2.12 \\
a b\end{array}$ & 5.73 & 21.4 & $\begin{array}{c}0.54 \\
a b\end{array}$ & 20.0 \\
\hline Folic acid & $\begin{array}{c}38.33 \\
\text { cd }\end{array}$ & $\begin{array}{c}32.50 \\
a b\end{array}$ & 70.83 & 32.8 & $\begin{array}{c}3.97 \\
a b\end{array}$ & $\begin{array}{c}2.14 \\
a b\end{array}$ & 6.06 & 28.4 & $\begin{array}{l}0.57 \\
a b\end{array}$ & 26.7 \\
\hline Nicotinic acid & $\begin{array}{c}53.00 \\
\mathrm{a}\end{array}$ & $\begin{array}{c}36.67 \\
a b\end{array}$ & 89.67 & 68.1 & $\begin{array}{c}5.16 \\
a b\end{array}$ & $\begin{array}{c}2.30 \\
\mathrm{a} \\
\end{array}$ & 7.46 & 58.1 & $\begin{array}{c}0.85 \\
a b\end{array}$ & 88.8 \\
\hline Pyridoxine & $\begin{array}{c}38.33 \\
\mathrm{~cd}\end{array}$ & $\begin{array}{c}26.00 \\
a b\end{array}$ & 64.33 & 20.6 & $\begin{array}{c}3.96 \\
a b\end{array}$ & $\begin{array}{c}2.09 \\
a b\end{array}$ & 6.05 & 28.2 & $\begin{array}{c}0.52 \\
a b\end{array}$ & 15.5 \\
\hline Thiamine & $\begin{array}{c}44.83 \\
\text { bc }\end{array}$ & $\begin{array}{c}37.83 \\
a b\end{array}$ & 82.66 & 54.9 & $\begin{array}{c}3.93 \\
a b\end{array}$ & $\begin{array}{c}2.32 \\
a\end{array}$ & 6.25 & 32.4 & $\begin{array}{c}0.77 \\
a b\end{array}$ & 71.1 \\
\hline Oxamyl & $\begin{array}{c}45.33 \\
\text { bc }\end{array}$ & $\begin{array}{c}31.50 \\
a b\end{array}$ & 76.83 & 44.1 & $\begin{array}{c}5.80 \\
a b\end{array}$ & $\begin{array}{c}2.26 \\
\mathrm{a}\end{array}$ & 7.06 & 49.6 & $\begin{array}{c}0.91 \\
a b\end{array}$ & 102.2 \\
\hline $\mathrm{N}$ alone & $\begin{array}{c}28.33 \\
e\end{array}$ & $\begin{array}{c}25.00 \\
b\end{array}$ & 53.33 & --- & $\begin{array}{c}3.45 \\
b\end{array}$ & $\begin{array}{c}1.27 \\
\mathrm{C}\end{array}$ & 4.72 & --- & $\begin{array}{c}0.45 \\
b\end{array}$ & -- \\
\hline $\begin{array}{l}\text { Plant free of } \mathrm{N} \\
\text { and untreated }\end{array}$ & $\begin{array}{c}33.33 \\
d\end{array}$ & $\begin{array}{c}35.67 \\
a b\end{array}$ & 69.00 & 29.4 & $\begin{array}{c}4.70 \\
a b\end{array}$ & $\begin{array}{c}1.6 \\
b\end{array}$ & 6.30 & 33.5 & $\begin{array}{c}0.73 \\
a b\end{array}$ & 62.2 \\
\hline
\end{tabular}

$\mathrm{N}=800 \mathrm{~J} 2$ of $M$. incognita

*Each figure represented the mean of three replicates.

Means in each column followed by the same letter(s) did not significantly differ at $(P<.05)$ according to Duncan's multiple range test.

Data as depicted in table (2) verify that all tested vitamins and organic acid were remarkably effective in reducing numbers of formed galls and 
eggmasses of $M$. incognita on okra root system when compared with the inoculated untreated check. It is interesting to notice that ascorbic acid as vitamin $\mathrm{C}$ and antioxidant was the ultimate efficacious treatment performing crucial reductions in number of galls and eggmasses by 82.7 and $96.6 \%$, respectively, followed by folic acid, nicotinic acid and thiamine with values of 96.6, 90.5 and $90.5 \%$ for eggmases number, respectively. Similar trend was obtained by folic acid, nicotinic acid and thiamine with values of $81.2,75.7$ and $75.7 \%$ for root galls number, respectively comparing to that of nematode alone. However, the least values of those nematode parameters were recorded by pyridoxine and citric acid which were amounted to 10.5 and $17.2 \%$; and 8.2 and $14.7 \%$, respectively. Moreover, oxamyl as a nematicide ranked first in reducing numbers of galls (96.9\%) and eggmasses (99.1\%), and showed significant differences with the tested treatments especially for galls number. Meanwhile, significant differences that was evident between all treatments and nematode alone for number of eggmasses per root system (Table 2).

Table 2: Effect of certain vitamins and organic acids on root galling and eggmasses of Meloidogyne incognita infecting okra under greenhouse conditions.

\begin{tabular}{|l|c|c|c|c|c|c|}
\hline Treatments & $\begin{array}{c}\text { No. of } \\
\text { Root galls }\end{array}$ & $\begin{array}{c}\text { Red. } \\
\%\end{array}$ & RGI $^{\star \star}$ & $\begin{array}{c}\text { No. of } \\
\text { eggmasses }\end{array}$ & $\begin{array}{c}\text { Red. } \\
\%\end{array}$ & El I** $^{\star *}$ \\
\hline Ascorbic acid & $\begin{array}{c}7.67 \\
\mathrm{~b}\end{array}$ & 82.7 & 2.0 & $\begin{array}{c}1.33 \\
\mathrm{C}\end{array}$ & 96.6 & 1.0 \\
\hline Citric acid & $\begin{array}{c}40.67 \\
\mathrm{a}\end{array}$ & 8.2 & 4.0 & $\begin{array}{c}33.00 \\
\mathrm{~b}\end{array}$ & 14.7 & 4.0 \\
\hline Folic acid & $\begin{array}{c}8.33 \\
\mathrm{~b}\end{array}$ & 81.2 & 2.0 & $\begin{array}{c}1.33 \\
\mathrm{C}\end{array}$ & 96.6 & 1.0 \\
\hline Nicotinic acid & $\begin{array}{c}11.00 \\
\mathrm{~b}\end{array}$ & 75.7 & 3.0 & $\begin{array}{c}3.67 \\
\mathrm{C}\end{array}$ & 90.5 & 2.0 \\
\hline Pyridoxine & $\begin{array}{c}39.67 \\
\mathrm{a}\end{array}$ & 10.5 & 4.0 & $\begin{array}{c}32.00 \\
\mathrm{~b}\end{array}$ & 17.2 & 4.0 \\
\hline Thiamine & $\begin{array}{c}11.00 \\
\mathrm{~b}\end{array}$ & 75.7 & 3.0 & $\begin{array}{c}3.67 \\
\mathrm{C}\end{array}$ & 90.5 & 2.0 \\
\hline Oxamyl & $\begin{array}{c}1.33 \\
\mathrm{c}\end{array}$ & 96.9 & 1.0 & $\begin{array}{c}0.33 \\
\mathrm{C}\end{array}$ & 99.1 & 1.0 \\
\hline N alone & $\begin{array}{c}44.30 \\
\mathrm{a}\end{array}$ & --- & 4.0 & $\begin{array}{c}38.67 \\
\mathrm{a}\end{array}$ & -- & 4.0 \\
\hline
\end{tabular}

$\mathrm{N}=800 \mathrm{~J} 2$ of $M$. incognita

*Each figure represented the mean of three replicates.

Means in each column followed by the same letter(s) did not significantly differ at (P < $0.05)$ according to Duncan's multiple range test .

${ }^{*} \mathrm{RGI}=$ Root gall index and ${ }^{* \star} \mathrm{El}=$ Eggmasses index acoording to Taylor and Sasser (1978).

Promising results were reported among tested treatments with the indices of root galls as well as eggmasses number where the lowest indices for those two nematode criteria was accomplished by oxamyl $(1.0 ; 1.0)$, ascorbic acid $(2.0 ; 1.0)$ and folic acid $(2.0 ; 1.0)$ as comparing to nematode alone (4.0;4.0), (Table 2). 
Refaei, A. R.

The obtained results indicate that vitamins or antioxidants or organic acids may share partially in inducing resistance in susceptible okra plants. For instance, vitamin C (ascorbic acid), in particular could successfully be used in plants to raise their resistant ability as speculated by Arrigoni et al.,(1976\&1977) who illustrated its mode of action and role to bring resistance in plants against nematode infection. They also directed the attention to the usage of plant cells to the compound for the synthesis of mitochondria hydroxyproline protein that control the development of cyanide- resistant respiration. Moreover, since plant growth depends on both cell division and cell expansion, it shows that ascorbic acid is involved in plant growth regulation by checking biosynthesis of hydroxyproline containing protein. Such process is presented by certain biological defense mechanisms in plants (Zacheo et al., 1977). The present results are also in accordance with those of Saeed (2005) in respect to ascorbic acid at $1000 \mathrm{ppm}$ concentration level as foliar spray on $M$. incognita infected soybean plants. Moreover, plants receiving nicotinic acid or thiamine showed considerable percentage increase of plant growth parameters, whereas the intermediate values of the same plant criteria recorded by folic acid. Similar trend, but lesser in values of the citric acid and pyridoxine materials. Meanwhile, similar results was reported by the tested treatments concerning the reduction percentages values of number of galls and eggmasses where the ascorbic acid ranked first, followed by folic acid, nicotinic acid and then thiamine but citric acid and pyridoxine had the least values in this respect. These results are in agreement with those of Al-Sayed (1990) in respect to ascorbic acid, Montasser (1990) in respect to vitamins, Hassan (1999) and Nour-El-Deen (2008) in respect to ascorbic acid, citric acid and thiamine. Moreover, results of this work also prove that vitamins, antioxidants and organic acids may participate in inducing resistant in susceptible plants to certain extent.

Conclusively, the tested compounds, and ascorbic acid in particular, have a biotic role in nematode-susceptible plants. They have been regarded as resistance inducers in such susceptible plants. However, many trials are also needed to be done to evaluate their economic use in such nematode control programs.

\section{REFERENCES}

Abdel-Momen, S. M. ; Hanaa, S. Zawam and A. E. Khalil (2005). Effect of certain mineral salts, organic acids, amino acids and growth regulators on reproduction of Meloidogyne javanica infecting sunflower. J. Agric. Sci. , Mansoura Univ. , 30(5) : 2853-2863.

Al-Sayed, A. A. (1990). The inhibitory effect of ascorbic acid on Meloidogyne javanica infecting tomato . Annals Agric. Sci., Moshtohor, 28(3):17371740.

Al-Sayed, A. A.and D. J. Thomason (1988). Meloidogyne incognita and tomato response to thiamine, ascorbic acid, L- arginne and L- glutamic acid . J. Nematol. 20(3): 451- 456. 
Arrigoni, O. ; R. Liso- Arrigoni and G. Colabrese (1976). Ascorbic acid as a factor controlling the development of cyanide-insensitive respiration. Science, 194: $332-333$

Arrigoni, O. ; R. Liso- Arrigoni and G. Colabrese (1977). Ascorbic acid requirement for biosynthesis of hydroxyproline containing proteins in plants. FEBS Letters, 82: 135-138.

Duncan, D.B. (1955). Multiple range and multiple, F-test. Biometrics, 11: 142.

Gomez, K. A. and A.A. Gomez (1984). Statistical procedures for Agricultural Research. $2^{\text {nd }}$ Ed., John Wiley \&Sons: Inc., New York.

Goodey, J.B. (1957). Laboratory methods for work with plant and soil nematodes. Tech. Bull. No. 2. Min. Agric. Fish Ed. London, pp 47.

Hassan, H. M. (1999). Effect of some antioxidants on the response of cucumber to Meloidogyne javanica infection and the activity of the plant peroxidase . Egyptian J. Agronematol., 3: 139 - 148.

Ibrahim, Mervat H. (2007). Effect of seed soaking in aqueous solution of ascorbic acid, indole acetic acid, lysine and thiamine on Meloidogyne javanica infected soybean. J. Agric. Sci., Masoura Univ., 32(11) :9463 $-9471$.

Kesba, H. H. H. (1999). Ecological and pathological studies on some plant parasitic nematodes infecting grape, Vitis vinifera L. M. Sc. Thesis, Fac. Agric., Cairo Univ., 114 pp.

Kesba, H. H. H. (2003). Integrated nematode management on grapes grown in sandiness soil. Ph. D. Thesis, Fac. Agric., Cairo Univ, 189 pp.

Luc, M. ; R. A. Sikora and J. Bridge (2005). Plant parasitic nematodes in subtropical and tropical agriculture. CAB International, Walling Ford, UK. $871 \mathrm{pp}$.

Molinari, S. (2001). Inhibition of $\mathrm{H}_{2} \mathrm{O}_{2}$-degrading enzymes in the response of Mi-bearing tomato to root-knot nematodes and salicylic acid treatment . Nematologia Mediterranea, 29 (2):235 - 239.

Montasser, S. A. (1990). Efficacy of certain vitamins in controlling the root knot nematode, Meloidogyne incognita on tomato. Pakistan J. Nematol., 8 (2) :101 -105.

Nandi, B.; K. Kundu ; N. Banerjee and S.P.S. Babu (2003). Salicylic acidinduced suppression of Meloidogyne incognita infestation of okra and cowpea. Nematology. Brill Academic publishers, Leiden, Netherlands, $5(5): 747-752$.

Nour El- Deen, A. H. H. (2008). Potential use of tissue culture technology in controlling plant parasitic nematodes. Ph. D. Thesis, Fac. Agric . Mansoura Univ., Egypt. 152 pp.

Osman, G. Y. (1993). Effect of amino acids and ascorbic acid on Meloidogyne javanica Chitw. (Tylenchidae, Nematoda). J. of Pest Science, 66 (7) : $140-142$.

Saeed, M. R. M. (2005). Utilization of some specific materials to stimulate resistance in some host plants against the root knot nematodes. Ph. D. Thesis, Fac. of Agric., Cairo Univ., 220 pp. 
Refaei, A. R.

Taylor, A. L. ; and J. N. Sasser (1978). Biology, identification and control of root-knot nematodes (Meloidogyne species). Coop. Publ., Dep. Plant pathol., North Carolina state Univ. and U.S. Agency Int. Dev. , Raleigh, N. C. 111 pp.

Zacheo, G. ; F. lamberti ; R. Arrigoni- Liso and O. Arrigoni (1977). Mitochondrial protein-hydroxyproline content of susceptible and resistant tomatoes infected by Meloidogyne incognita Nematologica, $34: 471$.

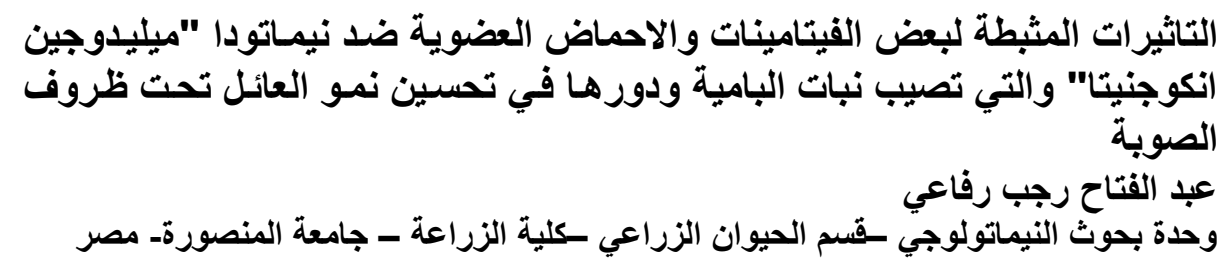

تم إجراء التجربة في أصص لاختبار تاثير ستة فيتامينات وهي حامض الاسكوربيك

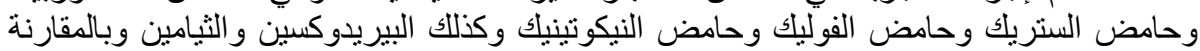

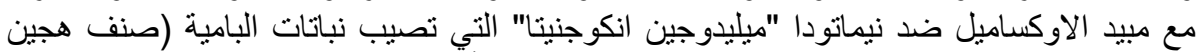

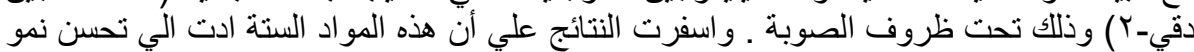

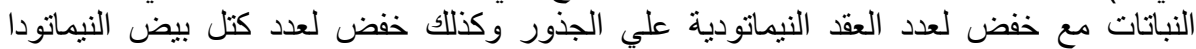

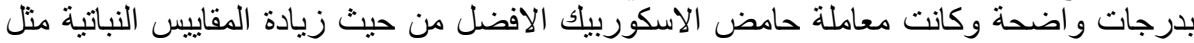

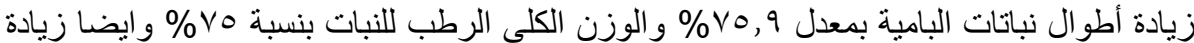

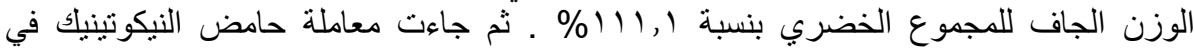

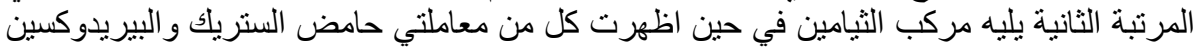

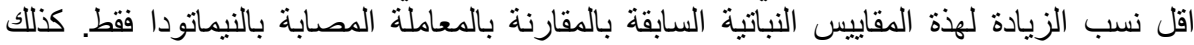

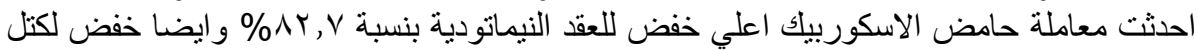

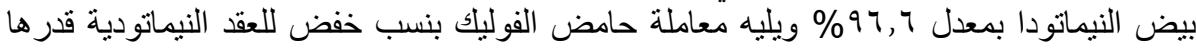

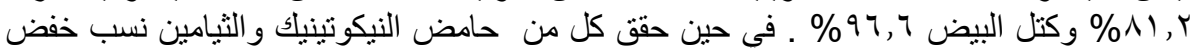

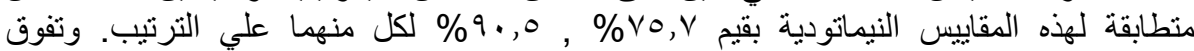

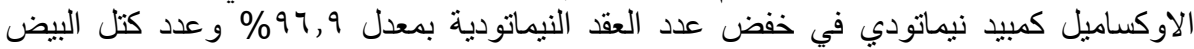

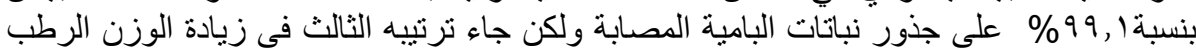

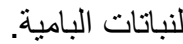

